\title{
Predictive Factors of Nivolumab-induced Hypothyroidism in Patients with Non-small Cell Lung Cancer
}

\author{
TOSHIYA MAEKURA ${ }^{1}$, MAIKO NAITO $^{1}$, MASAHIRO TAHARA ${ }^{1}$, NAOYA IKEGAMI $^{1}$, \\ YOHEI KIMURA ${ }^{1}$, SHOKO SONOBE ${ }^{1}$, TAKEHIKO KOBAYASHI ${ }^{1}$, TAISUKE TSUJI $^{1}$, \\ SHOJIRO MINOMO ${ }^{1}$, AKIHIRO TAMIYA $^{1}$ and SHINJI ATAGI ${ }^{2}$ \\ ${ }^{1}$ Department of Internal Medicine, National Hospital Organization \\ Kinki-Chuo Chest Medical Center, Osaka, Japan; \\ ${ }^{2}$ Department of Clinical Research Center, National Hospital Organization \\ Kinki-Chuo Chest Medical Center, Osaka, Japan
}

\begin{abstract}
Background/Aim: Although immune checkpoint inhibitors play an important role in the therapy of lung cancer, they are associated with various immune-related adverse events and predictive factors of them are unclear. In this study, we investigated predictive factors of nivolumab-induced hypothyroidism which is one of the adverse events in patients with lung cancer. Patients and Methods: Patients with nonsmall-cell lung cancer who were administered nivolumab at our hospital between December 2015 and May 2016 were retrospectively enrolled. The thyroid-stimulating hormone, free triiodothyronine, free thyroxine, thyroid peroxidase (TPO) antibody, and thyroglobulin antibody levels of each patient were analyzed. Results: Of the 64 patients enrolled, 5 (7.8\%) developed hypothyroidism after treatment with nivolumab. The TPO and thyroglobulin antibodies were significantly positive in patients who developed primary hypothyroidism. Conclusion: TPO and thyroglobulin antibody levels at baseline may be predictive of hypothyroidism.
\end{abstract}

In recent years, immune checkpoint inhibitors (ICIs) have played an important role in the therapy of non-small-cell lung cancer (NSCLC). The utility of ICIs (e.g., cytotoxic Tlymphocyte-associated antigen 4 , programmed death-ligand 1 , and programmed cell death protein 1 [PD-1]) for the

This article is freely accessible online.

Correspondence to: Dr. Toshiya Maekura, Department of Internal Medicine, National Hospital Organization Kinki-Chuo Chest Medical Center, 1180 Nagasone-Cho, Kita-Ku, Sakai City, Osaka 591-8555, Japan. Tel: +81 722523021, Fax: +81 722511372, e-mail: toshiya1027@gmail.com

Key Words: Hypothyroidism, lung cancer, nivolumab, thyroglobulin, thyroid peroxidase. treatment of NSCLC has been reported in many studies (14). Specifically, the anti-PD-1 antibody nivolumab has demonstrated superiority to docetaxel for progression-free survival and overall survival in patients with advanced NSCLC. Although the toxicity is milder than conventional chemotherapy (5), numerous immune-related adverse events have been reported as side effects of ICIs $(6,7)$. Thyroid dysfunction induced by nivolumab has been reported in 3-7\% of patients in other studies $(5,6,8)$. Even though hypothyroidism occurs as a result of immunotherapy, it is possible to continue immunotherapy with the appropriate administration of thyroid hormone (9). Since common symptoms of hypothyroidism are non-specific (e.g., loss of appetite and fatigue) $(10,11)$, these symptoms can be mistaken for symptoms of lung cancer. Therefore, we regularly evaluate thyroid function after administering nivolumab. However, the frequency of thyroid function tests and the patients who should be monitored for hypothyroidism have not yet been determined, because predictive factors of nivolumab-induced hypothyroidism are unknown.

In this study, we aimed to evaluate thyroid dysfunction in nivolumab-treated patients with NSCLC and to determine the predictive factors of hypothyroidism induced by nivolumab.

\section{Patients and Methods}

This study was approved by the Institutional Review Board (approval number: 581) of the National Hospital Organization KinkiChuo Chest Medical Center (Osaka, Japan). Research was conducted in accordance with the Helsinki Declaration and Title 45, US Code of Federal Regulations, Part 46, Protection of Human Subjects.

Patients. Patients with NSCLC who were administered nivolumab at our hospital between December 2015 and May 2016 were retrospectively analyzed. Patients were excluded if their thyroid function was not measured before or after the administration of nivolumab or they fulfilled the diagnostic criteria for hypothyroidism before treatment. 


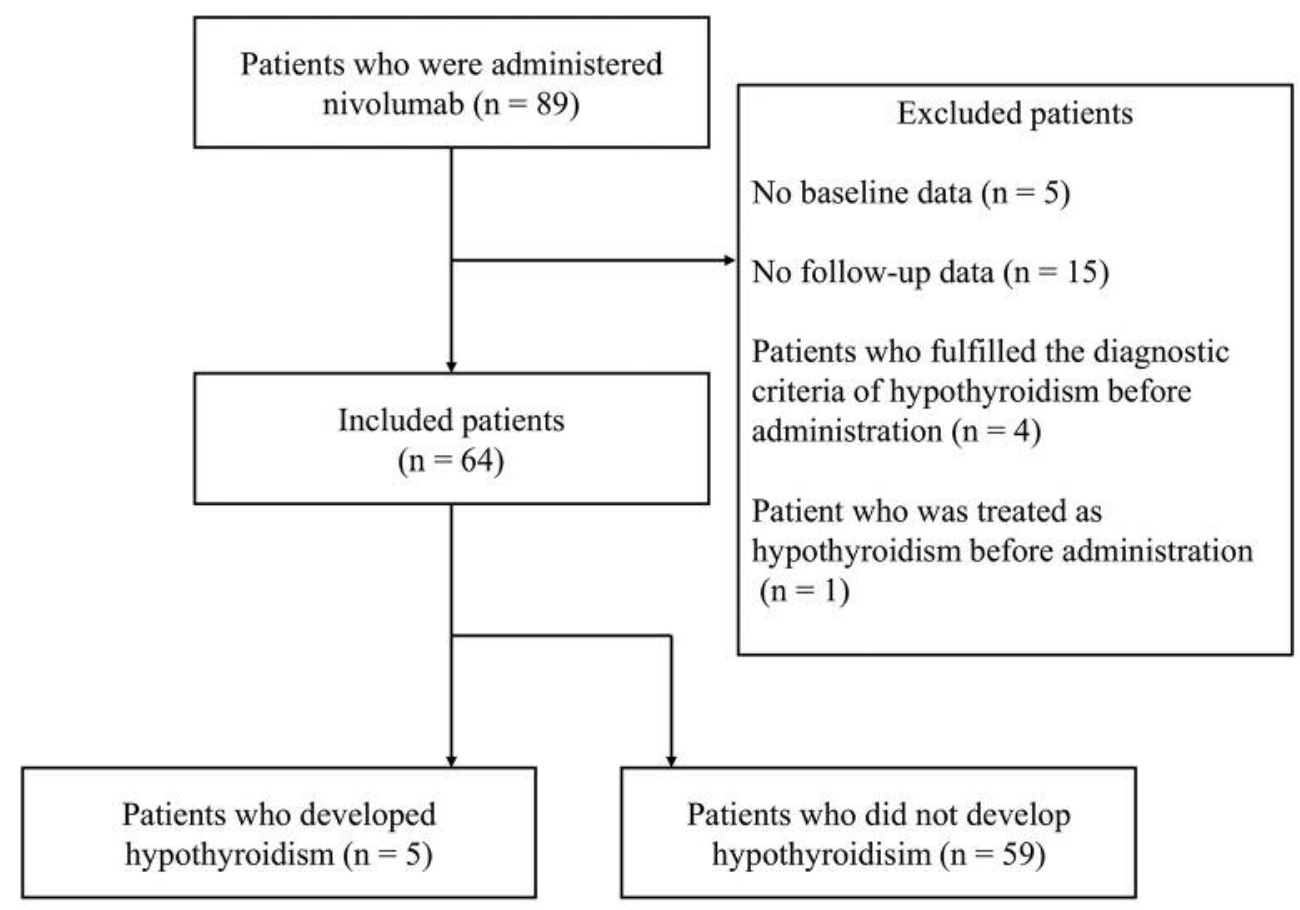

Figure 1. Algorithm of patient selection. Five of the 64 patients enrolled in this study developed hypothyroidism.

Thyroid function. Thyroid function was retrospectively assessed until 4 months after the administration of nivolumab or until the end of thyroid function measurements. Thyroid-stimulating hormone (TSH), free triiodothyronine, and free thyroxine levels were determined using chemiluminescence immunoassay. Thyroid peroxidase (TPO) and thyroglobulin antibodies were measured using electrochemiluminescence immunoassay. The reference ranges for TSH, free triiodothyronine, free thyroxine, TPO antibodies, and thyroglobulin antibodies were $0.27-4.20 \mu \mathrm{IU} / \mathrm{ml}, 2.6-5.1 \mathrm{pg} / \mathrm{ml}, 1.0-$ $1.8 \mathrm{ng} / \mathrm{dl}, \leq 16.0 \mathrm{IU} / \mathrm{ml}$, and $\leq 28.0 \mathrm{IU} / \mathrm{ml}$, respectively.

Diagnostic criteria for hypothyroidism. Patients with elevated TSH levels above the reference range and reduced free thyroxine levels below the reference range were diagnosed as having hypothyroidism. The severity of hypothyroidism was determined according to the Common Terminology Criteria for Adverse Events (version 4.0) (12).

Statistical analyses. All statistical analyses were conducted in JMP (version 11.0; SAS Institute Inc., Cary, NC, USA). Patient characteristics were compared using Wilcoxon and Fisher's exact tests. A $p$-value of $<0.05$ was considered statistically significant.

\section{Results}

Eighty-nine patients with NSCLC were administered nivolumab. Five patients were excluded due to a lack of baseline data from thyroid function tests. Fifteen patients were excluded due to a lack of follow-up data from thyroid function tests. Four patients were excluded because they fulfilled the diagnostic criteria for hypothyroidism before treatment. One patient was treated as having hypothyroidism before the administration of nivolumab.

Of the 64 patients enrolled in this study, 5 (7.8\%) developed hypothyroidism after treatment with nivolumab (Figure 1). The patient characteristics are summarised in Table I. There were 41 males and 23 females, with a median age of 68 years. A median total dosage of 6 courses was administered during the research period. Comparisons were made between patients who developed hypothyroidism and those who did not. The TPO and thyroglobulin antibodies were significantly positive in patients who developed primary hypothyroidism. Detailed information of the 5 patients who developed primary hypothyroidism is provided in Table II. The best response was progressive disease in 2 patients, stable disease in 1 patient, and a partial response in 2 patients. Three patients were treated with levothyroxine (a thyroid hormone agent). None of the patients developed hypothyroidism severe enough for treatment to be discontinued.

\section{Discussion}

In this study, we determined the utility of baseline TPO and thyroglobulin antibody levels as predictive factors of nivolumab-induced hypothyroidism in patients with NSCLC. Among the 5 patients who developed hypothyroidism, 4 were positive for TPO antibodies and 5 were positive for thyroglobulin antibodies. Differences between patients who 
Table I. Clinical characteristics of patients with nivolumab-treated lung cancer ( $n=64)$.

\begin{tabular}{|c|c|c|c|c|}
\hline \multirow[t]{2}{*}{ Characteristic } & \multicolumn{3}{|c|}{ Patients } & \multirow[t]{2}{*}{$p$-Value } \\
\hline & $\begin{array}{c}\text { All } \\
(\mathrm{n}=64)\end{array}$ & $\begin{array}{l}\text { Hypothyroidism+ } \\
\qquad(\mathrm{n}=5)\end{array}$ & $\begin{array}{l}\text { Hypothyroidism- } \\
\qquad(\mathrm{n}=59)\end{array}$ & \\
\hline Age (years), median (range)* & $68(46-86)$ & $63(57-68)$ & $68(46-86)$ & 0.066 \\
\hline \multicolumn{5}{|l|}{ Gender, $\mathrm{n}$} \\
\hline M & 41 & 3 & 38 & \multirow[t]{2}{*}{1.000} \\
\hline $\mathrm{F}$ & 23 & 2 & 21 & \\
\hline BMI, median (range)* & $21.4(14.4-37.8)$ & $21.0(14.4-24.3)$ & $21.4(15.4-37.8)$ & 0.871 \\
\hline \multicolumn{5}{|l|}{ Smoking status, $\mathrm{n}$} \\
\hline Current/former smoker & 44 & 4 & 40 & \multirow[t]{2}{*}{1.000} \\
\hline Non-smoker & 20 & 1 & 19 & \\
\hline \multicolumn{5}{|l|}{ ECOG PS, n } \\
\hline $0-2$ & 60 & 4 & 56 & \multirow[t]{2}{*}{0.284} \\
\hline $3-4$ & 4 & 1 & 3 & \\
\hline \multicolumn{5}{|l|}{ Best response, $\mathrm{n}$} \\
\hline $\mathrm{PD}$ & 26 & 2 & 24 & \multirow[t]{2}{*}{1.000} \\
\hline $\mathrm{SD} / \mathrm{PR}$ & 38 & 3 & 35 & \\
\hline \multicolumn{5}{|l|}{ Pathological diagnosis, $\mathrm{n}$} \\
\hline $\mathrm{ADC}$ & 52 & 4 & 48 & \multirow[t]{3}{*}{1.000} \\
\hline SCC & 10 & 1 & 9 & \\
\hline NSCLC & 2 & 0 & 2 & \\
\hline \multicolumn{5}{|l|}{ EGFR mutation status, $\mathrm{n}$} \\
\hline Positive & 18 & 1 & 17 & \multirow[t]{3}{*}{1.000} \\
\hline Negative & 39 & 3 & 36 & \\
\hline Unknown & 7 & 1 & 6 & \\
\hline Total dosage (courses), median (range)* & $6(1-12)$ & $8(3-11)$ & $5.5(1-12)$ & 0.356 \\
\hline \multicolumn{5}{|l|}{ TPOAb status, $\mathrm{n}$} \\
\hline Positive & 9 & 4 & 5 & \multirow[t]{3}{*}{$0.002 \dagger$} \\
\hline Negative & 44 & 1 & 43 & \\
\hline Unknown & 11 & 0 & 11 & \\
\hline \multicolumn{5}{|l|}{ TgAb status, $n$} \\
\hline Positive & 9 & 5 & 4 & \multirow[t]{3}{*}{$<0.001 \dagger$} \\
\hline Negative & 44 & 0 & 44 & \\
\hline Unknown & 11 & 0 & 11 & \\
\hline \multicolumn{5}{|l|}{ Thyroid function (baseline), median (range)* } \\
\hline TSH & $1.9(0.2-6.9)$ & $2.4(1.1-3.1)$ & $1.9(0.2-6.9)$ & 0.423 \\
\hline FT3 & $2.4(1.0-3.4)$ & $2.6(1.9-3.1)$ & $2.4(1.0-3.4)$ & 0.387 \\
\hline FT4 & $1.1(0.8-1.8)$ & $1.1(0.9-1.3)$ & $1.1(0.8-1.8)$ & 0.756 \\
\hline \multicolumn{5}{|c|}{ Thyroid function (after treatment), median (range)* } \\
\hline TSH (maximum) & $2.3(0.01-122.9)$ & $9.3(4.8-122.9)$ & $2.1(0.01-21.4)$ & $<0.001^{\dagger}$ \\
\hline FT3 (minimum) & $2.2(1.0-3.0)$ & $1.6(1.4-1.6)$ & $2.3(1.0-3.0)$ & $0.002^{\dagger}$ \\
\hline FT4 (minimum) & $1.0(0.6-2.5)$ & $0.7(0.6-0.9)$ & $1.0(0.7-2.5)$ & $<0.001^{\dagger}$ \\
\hline
\end{tabular}

*Range (minimum to maximum value). ${ }^{\dagger} p<0.05$. ADC: Adenocarcinoma; BMI: body mass index; ECOG: Eastern Cooperative Oncology Group; F: female; FT3: free triiodothyronine; FT4: free thyroxine; M: male; NSCLC: non-small-cell lung carcinoma; PD: progressive disease; PR: partial response; PS: performance status; SCC: squamous cell carcinoma; SD: stable disease; TgAb: thyroglobulin antibody; TPOAb: thyroid peroxidase antibody; TSH: thyroid stimulating hormone.

developed hypothyroidism and those who did not suggest that hypothyroidism induced by nivolumab is related to an immunological mechanism associated with these antibodies. Similarly, Alhusseini et al. (13) reported an immunological mechanism of hypothyroidism in cancer patients treated with ICIs (anti-PD1 agents alone or in combination with anticytotoxic T-lymphocyte-associated antigen 4 agents). The authors reported that, during the thyroiditis phase, $50 \%$ of the patients had elevated thyroglobulin antibodies, $40 \%$ had elevated anti-thyroglobulin antibodies, and a further $40 \%$ had elevated thyroid stimulating immunoglobulin antibodies (13). Tanaka et al. (14) reported on 3 cases of nivolumab-induced hypothyroidism. One patient had elevated TPO and thyroglobulin antibodies. Another had positive TPO 
in vivo $31: 1035-1039(2017)$

Table II. Clinical characteristics of patients with nivolumab-induced hypothyroidism ( $n=5)$.

\begin{tabular}{|c|c|c|c|c|c|}
\hline Characteristic & Case 1 & Case 2 & Case 3 & Case 4 & Case 5 \\
\hline Age (years) & 68 & 66 & 63 & 62 & 57 \\
\hline Gender & M & $\mathrm{F}$ & M & $\mathrm{F}$ & $\mathrm{M}$ \\
\hline Total dosage (courses) & 9 & 8 & 3 & 11 & 3 \\
\hline Prior therapy & CDDP+PEM & DOC & CBDCA+Nab-PTX & S-1 & $\mathrm{CDDP}+\mathrm{GEM}$ \\
\hline Best response & PR & $\mathrm{SD}$ & $\mathrm{PD}$ & PR & PD \\
\hline \multicolumn{6}{|c|}{ Thyroid function (baseline) } \\
\hline TSH & 3.0 & 2.4 & 1.7 & 3.1 & 1.1 \\
\hline FT3 & 1.9 & 2.4 & 3.0 & 2.6 & 3.1 \\
\hline FT4 & 1.2 & 1.0 & 1.3 & 1.1 & 0.9 \\
\hline \multicolumn{6}{|c|}{ Thyroid function (after treatment) } \\
\hline TSH (maximum) & 9.3 & 9.9 & 8.2 & 122.9 & 4.8 \\
\hline FT3 (minimum) & 1.6 & 1.6 & 1.6 & 1.4 & 1.4 \\
\hline FT4 (minimum) & 0.7 & 0.6 & 0.9 & 0.7 & 0.6 \\
\hline Grade* & 1 & 2 & 2 & 2 & 1 \\
\hline TPOAb & - & + & + & + & + \\
\hline $\operatorname{TgAb}$ & + & + & + & + & + \\
\hline
\end{tabular}

*Common Terminology Criteria for Adverse Event (version 4.0). CBDCA: Carboplatin; CDDP: cisplatin; DOC: docetaxel; F: female; FT3: free triiodothyronine; FT4: free thyroxine; GEM: gemcitabine; M: male; Nab-PTX: nab-paclitaxel; PD: progressive disease; PEM: pemetrexed; PR: partial response; S-1: tegafur, gimestat, otastat potassium; SD: stable disease; TgAb: thyroglobulin antibody; TPOAb: thyroid peroxidase antibody; TSH: thyroid stimulating hormone.

antibodies after treatment (14). The mechanism(s) of nivolumab-induced hypothyroidism are not fully understood. However, it has been reported that programmed death-ligand 1 and 2 are expressed in normal thyroid tissue, which suggests that nivolumab reduces the immune tolerance of normal thyroid tissue and that hypothyroidism develops via an immunological mechanism (15).

In addition to nivolumab, pembrolizumab, an anti-PD-1 antibody, is also known to induce hypothyroidism. Among 99 patients with melanoma who were treated with pembrolizumab, 17 presented with thyroid dysfunction. Thyroid auto-antibodies were elevated during thyroid dysfunction in 4 of 10 patients whose antibodies were assessed (16). Osorio et al. (17) reported that 10 of 48 pembrolizumab-treated patients who were not hypothyroid at baseline developed thyroid dysfunction. Anti-thyroid antibodies were present in 8 of 10 patients compared to 3 of 38 patients who did not develop thyroid dysfunction. Interestingly, overall survival with pembrolizumab was significantly longer in patients who developed thyroid dysfunction (17). Additionally, Tanaka et al. (14) have reported that 1 of 3 patients with melanoma who developed nivolumab-induced hypothyroidism achieved complete remission, although the relationship between tumor response and toxicity is unknown (14).

In this study, there was no significant difference in the best response between patients with and without hypothyroidism. However, a larger sample size is needed to assess the association between tumor response to ICIs and hypothyroidism. Expert opinion has suggested an algorithm of hormonal assays for monitoring immune-related endocrine disorders. In this algorithm, the evaluation of thyroid function and baseline anti-thyroid antibodies is recommended (10). Additionally, the time-to-onset of PD-1-inhibitor-induced hypothyroidism is reported to range from 0.7 weeks to 19 months and it is difficult to predict the occurrence time (18). Therefore, regular follow-up of thyroid function is also recommended. On the other hand, cases who have presented with ICI-induced thyroid dysfunction without an association with anti-thyroid antibodies have also been reported (19). Therefore, mechanisms other than immunological ones should also be considered. The treatment of hypothyroidism has been the replacement of thyroid hormone. Even in cases of asymptomatic subclinical hypothyroidism, patients with TSH levels of $>10.0 \mathrm{mIU} / \mathrm{l}$ should be treated according to the guidelines and review of thyroid treatment (20-22).

There are several limitations of this study. The first is its retrospective design and the fact that there are differences in the timing of the evaluation of thyroid function in each patient. The second is that, due to the restricted evaluation period, cases may have been missed that developed hypothyroidism after the evaluation period.

In conclusion, although the mechanism(s) of nivolumabinduced hypothyroidism are not fully understood, the evaluation of TPO and thyroglobulin antibodies at baseline may be predictive of hypothyroidism in patients with NSCLC. These patients should be carefully monitored for hypothyroidism induced by nivolumab. 


\section{Conflicts of Interest}

The Authors declare that they have no conflicts of interest.

\section{Acknowledgements}

The Authors would like to thank Editage (www.editage.jp) for English language editing.

\section{References}

1 Planchard D, Yokoi T, McCleod MJ, Fischer JR, Kim YC, Ballas M, Shi K and Soria JC: A Phase III study of durvalumab (MEDI4736) with or without tremelimumab for previously treated patients with advanced NSCLC: Rationale and protocol design of the ARCTIC study. Clin Lung Cancer 17: 232-236, 2016.

2 Valecha GK, Vennepureddy A, Ibrahim U, Safa F, Samra B and Atallah JP: Anti-PD-1/PD-L1 antibodies in non-small cell lung cancer: the era of immunotherapy. Expert Rev Anticancer Ther 17: 47-59, 2017.

3 Wang C, Yu X and Wang W: A meta-analysis of efficacy and safety of antibodies targeting PD-1/PD-L1 in treatment of advanced nonsmall cell lung cancer. Medicine (Baltimore) 95: e5539, 2016.

4 Zhou GW, Xiong Y, Chen S, Xia F, Li Q and Hu J: Anti-PD1/PD-L1 antibody therapy for pretreated advanced nonsmall-cell lung cancer: A meta-analysis of randomized clinical trials. Medicine (Baltimore) 95: e4611, 2016.

5 Borghaei H, Paz-Ares L, Horn L, Spigel DR, Steins M, Ready NE, Chow LQ, Vokes EE, Felip E, Holgado E, Barlesi F, Kohlhäufl M, Arrieta $\mathrm{O}$, Burgio MA, Fayette J, Lena H, Poddubskaya E, Gerber DE, Gettinger SN, Rudin CM, Rizvi N, Crinò L, Blumenschein GR Jr., Antonia SJ, Dorange C, Harbison $\mathrm{CT}$, Graf Finckenstein F and Brahmer JR: Nivolumab versus docetaxel in advanced nonsquamous non-small-cell lung cancer. N Engl J Med 373: 1627-1639, 2015.

6 Brahmer J, Reckamp KL, Baas P, Crinò L, Eberhardt WE, Poddubskaya E, Antonia S, Pluzanski A, Vokes EE, Holgado E, Waterhouse D, Ready N, Gainor J, Arén Frontera O, Havel L, Steins M, Garassino MC, Aerts JG, Domine M, Paz-Ares L, Reck M, Baudelet C, Harbison CT, Lestini B and Spigel DR: Nivolumab versus Docetaxel in advanced squamous-cell nonsmall-cell lung cancer. N Engl J Med 373: 123-135, 2015.

7 Chen TW, Razak AR, Bedard PL, Siu LL and Hansen AR: A systematic review of immune-related adverse event reporting in clinical trials of immune checkpoint inhibitors. Ann Oncol 26: 1824-1829, 2015.

8 Rizvi NA, Mazières J, Planchard D, Stinchcombe TE, Dy GK, Antonia SJ, Horn L, Lena H, Minenza E, Mennecier B, Otterson GA, Campos LT, Gandara DR, Levy BP, Nair SG, Zalcman G, Wolf J, Souquet PJ, Baldini E, Cappuzzo F, Chouaid C, Dowlati A, Sanborn R, Lopez-Chavez A, Grohe C, Huber RM, Harbison CT, Baudelet C, Lestini BJ and Ramalingam SS: Activity and safety of nivolumab, an anti-PD-1 immune checkpoint inhibitor, for patients with advanced, refractory squamous non-small-cell lung cancer (CheckMate 063): a phase 2, single-arm trial. Lancet Oncol 16: 257-265, 2015.

9 Spain L, Diem S and Larkin J: Management of toxicities of immune checkpoint inhibitors. Cancer Treat Rev 44: 51-60, 2016.
10 Rossi E, Sgambato A, De Chiara G, Casaluce F, Losanno T, Sacco PC, Santabarbara G and Gridelli C: Endocrinopathies induced by immune-checkpoint inhibitors in advanced non-small cell lung cancer. Expert Rev Clin Pharmacol 9: 419-428, 2016.

11 Ryder M, Callahan M, Postow MA, Wolchok J and Fagin JA: Endocrine-related adverse events following ipilimumab in patients with advanced melanoma: a comprehensive retrospective review from a single institution. Endocr Relat Cancer 21: 371-381, 2014.

12 National Cancer Institute Common Terminology Criteria for Adverse Events v4.0 NCI, NIH, DHHS. May 29, 2009 NIH publication \# 09-7473 https://evs.nci.nih.gov/ftp1/CTCAE/ CTCAE_4.03_2010-06-14_QuickReference_5x7.pdf

13 Alhusseini $M$ and Samantray J: Hypothyroidism in Cancer Patients on Immune Checkpoint Inhibitors with anti-PD1 Agents: Insights on Underlying Mechanisms. Exp Clin Endocrinol Diabetes 125: 267-269, 2017.

14 Tanaka R, Fujisawa Y, Maruyama H, Nakamura Y, Yoshino K, Ohtsuka $\mathrm{M}$ and Fujimoto $\mathrm{M}$ : Nivolumab-induced thyroid dysfunction. Jpn J Clin Oncol 46: 575-579, 2016.

15 Yamauchi I, Sakane Y, Fukuda Y, Fujii T, Taura D, Hirata M, Hirota K, Ueda Y, Kanai Y, Yamashita Y, Kondo E, Sone M, Yasoda A and Inagaki N: Clinical features of nivolumab-induced thyroiditis: A case series study. Thyroid 27: 894-901, 2017.

16 de Filette J, Jansen Y, Schreuer M, Everaert H, Velkeniers B, Neyns B and Bravenboer B: Incidence of thyroid-related adverse events in melanoma patients treated with pembrolizumab. J Clin Endocrinol Metab 101: 4431-4439, 2016.

17 Osorio JC, Ni A, Chaft JE, Pollina R, Kasler MK, Stephens D, Rodriguez C, Cambridge L, Rizvi H, Wolchok JD, Merghoub T, Rudin CM, Fish S and Hellmann MD: Antibody-mediated thyroid dysfunction during T-cell checkpoint blockade in patients with non-small-cell lung cancer. Ann Oncol 28: 583-589, 2017.

18 Villadolid $\mathbf{J}$ and Amin A: Immune checkpoint inhibitors in clinical practice: update on management of immune-related toxicities. Transl Lung Cancer Res 4: 560-575, 2015.

19 Torino F, Barnabei A, Paragliola R, Baldelli R, Appetecchia M and Corsello SM: Thyroid dysfunction as an unintended side effect of anticancer drugs. Thyroid 23: 1345-1366, 2013.

20 Garber JR, Cobin RH, Gharib H, Hennessey JV, Klein I, Mechanick JI, Pessah-Pollack R, Singer PA and Woeber KA; American Association of Clinical Endocrinologists and American Thyroid Association Taskforce on Hypothyroidism in Adults: Clinical practice guidelines for hypothyroidism in adults: cosponsored by the American Association of Clinical Endocrinologists and the American Thyroid Association. Endocr Pract 18: 988-1028, 2012.

21 Hennessey JV and Espaillat R: Diagnosis and management of subclinical hypothyroidism in elderly adults: A review of the literature. J Am Geriatr Soc 63: 1663-1673, 2015.

22 Pearce SH, Brabant G, Duntas LH, Monzani F, Peeters RP, Razvi S and Wemeau JL: 2013 ETA Guideline: Management of subclinical hypothyroidism. Eur Thyroid J 2: 215-228, 2013.

Received July 18, 2017

Revised August 7, 2017

Accepted August 8, 2017 